ПСИХІЧНІ РОЗЛАДИ В МЕЖАХ СОЦІОЛОГІЧНОЇ ПАРАДИГМИ

\title{
MENTAL DISORDERS WITHIN THE SOCIOLOGICAL PARADIGM
}

УДК 316.624

DOI https://doi.org/10.32843/2663-

5208.2020.13-1.10

\section{Іванова Т.В.}

к.психол.н.,

доцент касредри психології, політології

та соціокультурних технологій

Сумський державний університет
У статті проаналізовано підходи до інтерпретації психічних розладів у межах соціологічної парадигми. Показано їхню відмінність від медикалістичних і біологізаторських моделей. Описано підходи до інтерпретації психічних захворювань - соціального конструктивізму, інтерактивного соціального конструктивізму та концепції деструктивної дисфункції. 3 позицій соціального конструктивізму психічні захворювання є відображенням соціальних цінностей і владних відносин. Інтерактивний соціальний конструктивізм описує концепцію психічного розладу як результат взаємодії культурних категорій, соціальних норм та індивідуальних реакцій на зовнішні впливи. Формування картини хвороби з позицій інтерактивного соціального конструктивізму $\epsilon$ елементом соціальної класифрікації в контексті інституційних практик $i$ соціальних значень. Недоліками конструкціоністської парадигми $\epsilon$ невідповідність релятивістських соціальних концепцій універсалістським природним концепціям, неможливість оцінити ступінь соціального оцінювання, а також відсутність об'єктивних критеріїв для оцінювання психічного захворювання. Перспективною в плані глибокого розуміння психічних розладів є концепція деструктивної диссрункції. Вона намагається поєднати біологічні та психологічні передумови розладу й соціальні умови його розгортання. Також концепція деструктивної дисфункції дає можливість розрізнити психічні розлади, що виникають у випадку не виконання певними внутрішніми психологічними механізмами власного природного призначення, від інших видів відхилень, пов'язаних з вадами, зокрема, виховання або зі специфрічними особливостями соціалізації. Концепція деструктивної дисфункції також дає змогу відрізнити основні психічні дисфуннкііі, які є універсальними, від ідіоматичних виразів симптомів, що сорормовані під впливом культури, надаючи таким чином передумови для встановлення об'єктивного розуміння межі психічного розладу. Ключові слова: психічний розлад, конструктивізм, інтерактивний соціальний конструктивізм, деструктивна диссрункція, біологізаторська модель, норми.

The article analyzes the approaches to the interpretation of mental disorders within the sociological paradigm. Their difference from the medical and biological models is shown. Approaches to the interpretation of mental illness - social constructivism, interactive social constructivism and the concept of destructive dysfunction - are described. From the standpoint of social constructivism, mental illness is a reflection of social values and power relations. Interactive social constructivism describes the concept of mental disorder as a result of the interaction of cultural categories, social norms and individual responses to external influences. Formation of the "picture of the disease", from the standpoint of interactive social constructivism, is an element of social classification in the context of institutional practices and social values. The disadvantages of the constructionist paradigm are the juxtaposition of the relativism of social concepts to the universalism of natural concepts, the inability to assess the degree of social assessment, and the absence of objective criteria for the evaluation of mental illness. The concept of destructive dysfunction is promising in terms of a deeper understanding of mental disorders. It attempts to combine biological and psychological approaches to understanding the disorder as well as the social conditions of its existence. It also makes it possible to distinguish mental disorders as a result of psychological dysfunctions from other types of deviations associated with disadvantages, in particular, upbringing or with specific features of socialization. The concept of destructive dysfunction also distinguishes basic psychiatric dysfunctions, which are universal, from idiomatic expressions of symptoms formed under the influence of culture, thus providing the preconditions for establishing an objective understanding of the boundary of mental disorder.

Key words: mental disorder, constructivism, interactive social constructivism, destructive dysfunction, biological model, social norms.
Постановка проблеми. Психічні захворювання $€$ фактором ризику в процесі соціальної інтеграції людини й у разі зменшення її здатності до адаптації. Слід зазначити, що в межах різних наукових дисциплін $€$ власна парадигма, що охоплює феноменологію й інтерпретацію причин виникнення, а також особливості перебігу психічного розладу.

У межах психіатрії й дотичних до неї спеціальностей психічні захворювання розглядаються як індивідуальні особливості характеру або мислення. Це припущення стало основою для офіційної класифікації психічних розладів - Діагностичного й статистичного посібника з психічних розладів (DSM) Американської психіатричної асоціації [1]. У цьому посібнику зазначається, що його різні діагностичні критерії мають певну об'єктивну реальність і $€$ універсальними. Звідси випливає цілком слушний висновок, що симптоми, які супроводжують певний діагноз, можна порівняти, класифікувати й виміряти. Ці медикалістичні й біологізаторські моделі використовуються як базові спеціалістами відповідного профілю, що визначають, вивчають і лікують психічні захворювання. Таким чином, в основі медико-біологічної парадигми лежать уявлення про те, що психічні розлади виникають внаслідок генетичної схильності або прямого ураження центральної нервової системи, вони обов'язково 
базуються на певному мозковому субстраті, їх перебіг має процесуальний характер, а клінічні феномени є зовнішнім вираженням внутрішніх біологічних змін. Психічні захворювання, таким чином, являють собою нозологічні форми, лікування яких насамперед орієнтовано на корекцію біологічних механізмів патогенезу.

Аналіз останніх досліджень і публікацій. Відповідно до соціологічної парадигми психічні розлади не можуть бути поза базовими структурами суспільства, а їхня клінічна симптоматика часто є способом самовираження й комунікації. Хвороби, таким чином, можна розглядати як певні соціальні ролі, корекція яких полягає в зміні засвоєних стереотипів реагування й життєвих сценаріїв.

На відміну від загальноприйнятих психіатричних поглядів на психічні захворювання, соціологія вивчає соціальну обумовленість виникнення психічних розладів, а також їхнє значення й розуміння в системі соціальних цінностей і норм. Соціологія фокусується на колективній інтерсуб'єктивності соціального виміру на відміну від суб'єктивних внутрішніх світів індивідів, а також від об'єктивних універсальних світів природних об'єктів [2]. Ця перспектива підкреслює формування простору досвіду на основі взаємодії соціальних суб'єктів, культурних передумов і суспільних практик. Тобто в самому широкому сенсі продукування будь-якого знання, у тому числі наукового, відбувається за певних історичних і соціальних умов. Соціальні процеси впливають на класифікацію знань, а також на інститути, практики й моделі поведінки, у які вбудовані ці знання.

3 цих позицій невирішеним питанням у соціології психіатричного діагнозу є вивчення взаємозв'язків між культурно закладеними припущеннями про психічні захворювання й будь-якою природною реальністю, що лежить в основі цих розладів. У соціальному аспекті здоров'я або хвороба - відносні поняття. Вони мають свою реальність і своє значення та існують лише всередині культурних, соціальних й історичних чинників [3].

Орієнтація на пошук об'єктивних біологічних критеріїв, що встановлюють межу між нормою й патологією, не враховує той факт, що діагноз психічного розладу $€$ соціальним конструктом, тобто результатом деяких договорів, укладених на основі наявностіпевних симптомів, з одного боку, і пов'язаним із цим низьким рівнем соціальної адаптації індивіда, 3 іншого. Відповідно встановлення діагнозу залежить від розташування умовного порогу відповідності на континуумі нормативності, а не на реальній оцінці гіпотетичних біомаркерів [3].

Умовність границі між психічною нормою й патологією підкреслював ще К. Ясперс, який зазначав, що концепція хвороби в психіатрії почала застосовуватися набагато пізніше, ніж у соматичній медицині. Досить довгий час причиною психічних захворювань вважалися певні надприродні сутності (демони або гріх), водночас люди з психічними відхиленнями продовжували співіснувати з суспільством, утворюючи певну субкультуру. Різке збільшення починаючи з XIX століття кількості осіб, які вважалися психічно хворими й потребували спеціального нагляду у лікарнях, К. Ясперс пов'язує з ускладненням суспільства й неможливістю таким людям пристосуватися до сучасних вимог [5]. Наведені положення вказують на те, що природничо-натуралістична парадигма за класифікації психічних розладів не враховує соціальне походження конструкту «психічна патологія» й культуральну обумовленість його критеріїв, намагаючись виділити «природні» матеріальні критерії психічної патології.

Ідея соціального конструктивізму, запропонована П. Бергером і Т. Лукманом [6], виявилася напрочуд ефективною в плані пояснення соціальної реальності, у тому числі у сфері побудови психіатричного діагнозу. Розглянемо уявлення про психічні дисфункції, що сформувались у теперішній час у межах різних напрямів конструктивізму.

Класичний конструктивізм орієнтується на пояснення психічних захворювань через їхню культурно-нормативну опосередкованість. Зокрема, джерелами класичного конструктивізму в дослідженні психічних відхилень $€$ вивчення співвідношення феноменології сучасних категорій розладів у межах парадигми культурного релятивізму. М. Фуко розглядав психічне захворювання як соціальну й історичну, а не медичну проблему. Він стверджував, що психічне захворювання є насамперед суспільно-історичним явищем: уявлення про божевілля змінюється в історії й пов'язано з нормами й цінностями певного суспільства. В основі розподілу психічної норми й психічного розладу, на думку Фуко, лежить певний владний наратив, який, прагнучи стати метанаративом, пригнічує інші наративи й можливості, які можуть обмежувати або навіть загрожувати існуванню владних інституцій [7].

Психічні захворювання, таким чином, $€$ відображенням соціальних цінностей: люди, які вважаються психічно хворими, є порушниками певних видів соціальних норм. Механізми та процес отримання ярлика девіанта описав у теорії стигматизації Т. Шефф [8]. Він показав, що психічні й емоційні норми не $€$ частиною світу природи, а випливають із соціальних правил, що підсилюються силовими структурами й закріплюються владними нормативами. Т. Шефф робить висновок, що, оскільки норми є соціальним продуктом, психічні захворювання не мають універсальної основи й демонструють істотні відмінності залежно від часу й місця. 
Оскільки психічні захворювання, так само як і звичаї, цінності й норми, є соціальними артефактами, вони не можуть бути універсальними. Тобто визначення психічного розладу випливає з культурно-специфічного навчання, на що звертає увагу психолог і філософ Д. Болтон [9]. Він аналізує розуміння й інтерпретування психічного розладу в межах існування соціальних норм. Психіатричні симптоми не $є$, по суті, патологічними, але являють собою відхилення від оцінних норм відповідної поведінки, нормальність - це оцінка іншої людини як такої, що схожа на інших, а ненормальність - такої, що відрізняється від інших. Для Д. Болтона межа між нормальністю й відхиленням є дуже непевною й розпливчастою, тобто об'єктивні стандарти психічних розладів відсутні. Єдиним об'єктивним чинником психічного відхилення, за Д. Болтоном, є несприятливі наслідки для індивіда, до яких може призвести наявність у нього психічних розладів. Недоліками конструктивістської парадигми можна назвати орієнтацію на прирівнювання психічного розладу до порушень соціальних норм. Твердження про те, що психічний розлад є виключно оцінювальною концепцією, не дозволяє відрізнити психічне захворювання від інших форм девіацій, які також порушують соціальні норми. Друга проблема класичного конструктивістського погляду полягає в поєднанні культурно обумовлених симптомів з біологічними проявами розладів. Наприклад, підвищена емоційність може відображати певні культурні моделі поведінкових реакцій, а може бути проявом біологічних, біохімічних процесів. Третя проблема класичного соціального конструктивізму полягає в його нездатності враховувати будь-які природні наслідки хвороби, що виникають незалежно від її соціальної класифікації. Спотворені розумові процеси за шизофренії, постійного вживання алкоголю або у випадку біполярних розладів можуть мати реальні наслідки незалежно від соціальних визначень чи діагнозів. Навіть якщо ми відмовимося називати певну поведінку патологічною, це не змінить її реальних негативних наслідків як для оточення, так і для самого носія цих розладів. По-четверте, суто конструктивістським поглядам бракує будь-якої об'єктивної концепції, яка могла б стати основою для критики конкретних поглядів на психічний розлад. В результаті вони обмежуються критикою психіатричних поглядів, не даючи продуктивних підстав навіть для порівняння підходів до психічних відхилень у різні історичні періоди або в різних суспільствах. Нарешті, можливо, основний недолік чисто конструктивістських поглядів полягає в тому, що вони вважають природу й культуру двома протилежними силами. Для них соціальні цінності й культурні процеси відрізняються від природних явищ, а не доповнюють їх.
Постановка завдання. В запропонованому дослідженні передбачається провести аналіз взаємодії природних і культурних чинників у контексті існування психічних розладів з позицій теорій, що працюють у межах інтерактивного соціального конструктивізму.

Виклад основного матеріалу дослідження. Інтерактивний соціальний конструктивізм не ставить собі за мету побудувати універсальну концепцію психічного розладу. Натомість він зосереджується на аналізі взаємодії культурних категорій, соціальних норм й індивідуальних реакцій на зовнішні впливи. Інтерактивний конструктивізм наголошує, що соціально-культурні концепції психічного розладу формують поведінку людей і зовнішню репрезентацію відхилення. Іншими словами, $€$ певні біологічні маркери психічного розладу, але вплив соціуму й культурних категорій призводить до того, що відбувається зміна зовнішніх ознак певних розладів і їх налаштування під варіанти «правильного» розладу.

Найбільш чітко позиція інтерактивного погляду на соціальний конструктивізм викладена в роботах Я. Хакінга [10]. Перш за все він констатує існування фундаментальної відмінності між психічними й фізичними захворюваннями. Фізичні захворювання мало залежать від суб'єктивних класифікацій: культурні припущення про роботу тілесних органів практично не впливають на перебіг основного характеру захворювання. Навпаки, класифікація психічних захворювань може глибоко змінити те, яким чином людина інтерпретує власну поведінку й реагує на отримання певного психіатричного діагнозу чи навіть результатів психологічного тестування. Я. Хакінгвикористовує дослідження конкретних психічних захворювань, щоб проілюструвати, яким чином інформованість щодо психічного розладу впливає на його репрезентацію: людина активно змінює свою поведінку, щоб відповідати певним симптомам. Він описує ефект зациклення, за якого маркування людей тим або іншим способом змушує їх змінювати свою поведінку в межах професійних медичних класифікацій. Водночас істинність або хибність припущень щодо причин психічних розладів не відіграє принципової ролі: значення соціальних конструкцій як моделі для побудови симптоматики розладу полягає в тому, що сукупність категорій, затверджених офіційною науковою спільнотою, опосередковують суб'єктивні когнітивні й поведінкові моделі конкретної людини. Індивід вибудовує систему пояснень причин й історію власної хвороби, використовуючи певні культурні наративи, що допомагають вербалізувати його переживання й структурувати всю сукупність емоційних, фізіологічних, поведінкових реакцій у взаємопов'язану спільність симптомів, які відповідають певному категоріальному опису стану хвороби. 
Інтерактивні концепції психічного розладу описують процес формування «картини хвороби» не просто як результату суб'єктивних ментальних практик, але як елемента соціальної класифікації, поміщаючи ї̈ в інституційні практики, соціальні значення та взаємодії. Вони уникають проблем суто конструктивістської перспективи завдяки відсутності протиставлення релятивістських соціальних концепцій універсалістським природним критеріям, навпаки, підкреслюючи момент взаємодії та взаємопроникнення природного та соціального. Один з недоліків інтерактивних концепцій психічного розладу полягає в тому, що вони не розрізняють ступінь, за якого різні види станів отримують певну соціальну оцінку (наприклад, шизофренія може бути менш сприйнятливою до соціального маркування, ніж анорексія або булімія). Інший недолік інтерактивних концепцій полягає в тому, що, не маючи уявлення про те, що є природним, вони не можуть оцінювати й критикувати адекватність або неадекватність різних концепцій психічного захворювання.

Указані недоліки намагається зняти Дж. Вейкфілд в концепції деструктивної дисфункції [11]. Деструктивну дисфункцію він розуміє як певний стан, який отримує подвійне негативне оцінювання. 3 одного боку, це стан, який негативно оцінюється соціальними інституціями або культурними нормативами, а з іншого боку, це розлад, який дійсно $є$ наслідком дисфункції певних психофізіологічних факторів. Таким чином, концепція деструктивної дисфункції відрізняє її як від класичного конструктивізму, так і від інтерактивної версії соціального конструювання. Деструктивна дисфункція розходиться з цими двома точками зору, оскільки передбачає, що природне біологічне функціонування психологічних механізмів, а також соціальних цінностей має бути включено в адекватні пояснення психічних розладів.

Психічні розлади у цьому випадку розглядаються як результат нездатності індивіда адаптуватися до соціокультурного середовища. Слід зазначити, що психологічні дисфункції з позицій такого підходу розглядаються як концептуально еквівалентні фізичним дисфункціям. Подібно до того як серце призначене для перекачування крові або легені для дихання, так і еволюційні психологічні процеси пізнання, мотивації, емоцій, виконують певні біологічно обумовлені функції: страх виникає у відповідь на небезпеку, сум супроводжує втрату, гнів $€$ ознакою відчуття несправедливості тощо. Таким чином, психічний розлад виникає у випадку нездатності певного психологічного механізму виконувати свою природну функцію, тобто функцію, яка сформувалась у процесі еволюційного розвитку.

Дж. Вейкфілд описує критерії, за якими розрізняються психічні та фізичні розлади.
Психічні дисфункції за своєю суттю є контекстуальними, тобто вони проявляються в межах соціальних і культурних нормативів. За своєю суттю психічні дисфункції мають плинні межі, які своєю чергою залежать від контексту їх утілення та прояву. Якщо фізичне функціонування відбувається перш за все в межах логіки існування біологічного організму, на який соціум чинить опосередкований вплив через систему соціальних практик, умов або стилю життя, які не відключаються, але працюють безперервно, то психологічні механізми призначені для спрацьовування в певних контекстах і не виникають за відсутності відповідних тригерів.

Нормальність функціонування й реагування біологічного організму підпорядкована закону гомеостазису й залежить насамперед від внутрішнього середовища. Нормальність психічного реагування залежить від соціокультурних факторів. Визначення того, що є відповідним або невідповідним контекстом для виникнення емоції або певного психічного стану, є набагато складнішим порівняно з вивченням меж норми для фізичного функціонування.

Таким чином, існування психічного розладу без урахування соціокультурного контексту, у якому він проявляється, значно ускладнює його інтерпретацію. Дж. Вейкфілд згадує про неписьменність, що сама по собі не вважається розладом, хоча й може певним чином утруднити соціальну адаптацію, але, з іншого боку, неписьменність, що виникає внаслідок нездатності вчитися через деякі внутрішні неврологічні вади, вважається розладом.

Подальше вивчення психологічних дисфункцій показало, що деякі з них можна вважати універсальними. Як приклад можна навести вивчення механізмів реагування на втрати А. Хорвіцем та Дж. Вейкфілдом [12]. Незважаючи на те що еволюційні функції механізмів реагування на втрату не повністю відомі, порівняльні результати досліджень приматів і людини в культурному різноманітті показало існування в індивіда біологічних механізмів, які активізуються в ситуаціях широкого спектра втрат - від втрати близької людини до позбавлення соціальних статусів або смислових уподобань. Примати також демонструють явну схожість з людьми в особливостях прояву, поведінки й функціонування мозкових структур у ситуаціях втрати. Більш того, схильність людини сумувати у відповідь на втрату проявляється дуже рано, перш ніж немовлята засвоюють культурно прийнятні способи вираження смутку. Широкі міжкультурні й історичні дослідження показують значну схожість прояву втрати в самих різних культурних контекстах, з чого А. Хорвіц і Дж. Вейкфілд роблять висновок, що механізми прояву й переживання втрати, імовірно, є наслідком еволюції людини як виду. Разом із тим біологічні джерела пере- 
живання смутку жодним чином не виключають важливих соціальних контекстів у конкретних типах ситуацій, які викликають реакції на втрати, різноманіттяповедінкового реагування у відповідь на втрату й норми, що стосуються належного вираження смутку. Тобто, з одного боку, культурні й соціальні фактори відіграють істотну роль у формуванні емоційного реагування, але, з іншого боку, вони тільки певним чином конструюють, змінюють реакції, які вже має людина, тобто є біологічно вбудованими.

Висновки 3 проведеного дослідження. Концепція деструктивної дисфункції вирізняється тим, що негативне соціальне оцінювання, ярлики та стигми, на які звертається увага в контексті класичного соціального конструктивізму не є достатніми умовами для констатування наявності розладу. Навіть коли певна поведінка отримує негативні соціальні оцінки, вона може бути віднесена до девіації, але не до психічних порушень внаслідок відсутності біопсихологічних умов її розвитку.

Концепція деструктивної дисфункції має ряд сильних сторін. ї̈ центральне поняття - «дисфункція» поєднує внутрішні відхилення (біологічні та психологічні передумови) й соціальні умови їх розгортання. Крім того, зазначена концепція надає можливість відрізнити психічні розлади, що виникають у випадку не виконання певними внутрішніми психологічними механізмами власного природного призначення, від інших видів відхилень, пов'язаних з вадами, зокрема, виховання або зі специфічними особливостями соціалізації, які ми можемо відносити до девіацій, тобто поведінкових відхилень від соціальних і культурних норм.

Крім того, концепція деструктивної дисфункції допомагає відрізнити основні психічні дисфункції, які є універсальними, від ідіоматичних виразів симптомів, сформованих під впливом культури. Концепція деструктивної дисфункції також надає певні передумови для встановлення об'єктивного розуміння межі психічного розладу. Можна стверджувати, що стан, який не $є$ тотально дисфункційним, не є розладом.

Нарешті, концепція деструктивної дисфункції корисна для розрізнення чітких полюсів між хворобливим і дезадаптивним станами й водночас сумісна 3 невизначеністю, нечіткістю й неоднозначністю між різними психічними розладами. Іншимисловами, культурайсоціум, а не природа встановлюють межі між визначеннями нормальності й патології, які трапляються в будь-якому конкретному часі й місці.

Концепція деструктивної дисфункції, приймаючи об'єктивність природних психічних розладів, одночасно визнає, що соціокультурна нормативність опосередковує як прояви психічних розладів, так і зовнішнє реагування на них. Природа й культура не дають проти- лежних пояснень, але є частинами єдиної концепції психічного розладу, що взаємодоповнюють одна одну.

Концепція деструктивної дисфункції має значний потенціал розвитку. Незважаючи на певні здобутки у вивченні психології та психофізіології патологічних емоційних станів, питання соціології емоцій та, зокрема, соціології емоційних розладів залишається поки що на стадії первинних припущень. Крім того, наявні широкі соціальні й культурні варіації інтерпретації терміна «психічний розлад», що теж потребує глибокого вивчення й осмислення.

\section{ЛIТЕРАТУРА:}

1. Regier D.A., Kuhl E.A., Kupfer D.J. The DSM-5: Classification and criteria changes. World Psychiatry. 2013. V. 12. № 2. P. 92-99. URL: https://onlinelibrary. wiley.com/doi/full/10.1002/wps.20050.

2. Шютц А. Смысловая структура повседневного мира: очерки по феноменологической социологии / пер. на рус. А.Я. Алхасов, Н. Я. Мазлумянова. Москва, 2003. [Электронный ресурс]: Центр гуманитарных технологий. 26 марта 2012 г. URL: https://gtmarket.ru/laboratory/basis/5584.

3. Фуко М. Психиатрическая власть : курс лекций, прочитанный в Коллеж де Франс в 1973-1974 учебном году / пер. с фрранц. А. Шестакова. Санкт-Петербург : Наука, 2017. 450 с.

4. Кравченко С.А. Десять тезисов о влиянии нелинейной социокультурной динамики на институт здоровья. Проблемы взаимодействия человека, культуры и общества в условиях глобализирующегося мирового пространства. Москва : Прометей, 2016. C. 83-88.

5. Ясперс К. Общая психопатология. Москва : Практика, 1997. 1053 с.

6. Бергер П., Лукман Т. Социальное конструирование реальности. Трактат по социологии знания. Москва : Медиум, 1995. 323 с.

7. Фуко. История безумия в классическую эпоху. Санкт-Петербург, 1997. 576 с.

8. Теория стигматизации Томаса Шефффа: концепт «Остаточное отклонение» и социология эмоций. Вестник Самарской гуманитарной академии. Серия «Философрия. Филология». Самара. 2013. № 1 (13). С. 31-48.

9. Следует ли рассматривать психические расстройства в качестве заболеваний головного мозга? Научные взгляды XXI века и их значение для исследовательской и образовательной деятельности D. Bolton. Всемирная психиатрия. 2012. T. 12. № 1. C. 21-23. URL: http://t-pacient.ru/wp-content/ uploads/2015/02/WPA12-12013.pdf.

10. Hacking I. The Social Construction of What? Harvard University Press, 1999. 262 p. URL: https://larvalsubjects.files.wordpress.com/2011/01/ hacking-the-social-construction-of-what2.pdf.

11. Wakefield J. C. The concept of mental disorder: diagnostic implications of the harmful dysfunction analysis. World Psychiatry. 2007. Oct; 6 (3). P. 149-156. URL: https://www.ncbi.nlm.nih.gov/pmc/articles/PMC2174594/.

12. Horwitz A.V. Wakefield J.C. The loss of sadness: how psychiatry transformed normal sorrow into depressive disorder. New York : Oxford University Press, 2007. 249 p. 